\title{
PROFIL PENGGUNAAN OBAT ANTIBIOTIK GOLONGAN PENISILIN DI APOTEK RAWAT JALAN RSUD KUALA KURUN
}

\section{Profile of Use of Penicillin Class of Antibiotic in Outpatient Pharmacy at Kuala Kurun Hospital}

\author{
*Nurul Chusna, Guntur Satrio Pratomo, \& Lisa Murwanda \\ Department of Pharmacy, Faculty of Health Science, Universitas Muhammadiyah Palangkaraya, RTA. Milono St. Km. I.5 Palangka Raya, \\ Indonesia \\ *e-mail : nurulchusna99@gmail.com
}

\begin{abstract}
ABSTRAK
Antibiotik adalah zat kimia yang dihasilkan oleh bakteri, yang memiliki khasiat mematikan atau menghambat pertumbuhan kuman, sedangkan toksisitasnya bagi manusia relatif kecil. Berdasarkan hasil observasi, penisilin merupakan golongan antibiotik yang banyak digunakan di RSUD Kuala Kurun khususnya pada pasien rawat jalan. Golongan penisilin adalah antibiotik yang paling dasar digunakan untuk pasien yang terkena infeksi karena berspektrum rendah atau lebih sederhana dalam menghambat pertumbuhan bakteri. Penelitian ini bertujuan untuk mengetahui profil penggunaan obat antibiotik golongan penisilin di RSUD Kuala Kurun. Metode yang digunakan dalam penelitian ini adalah metode deskriptif, populasi dalam penelitian ini adalah semua resep pasien rawat jalan yang mencantumkan antibiotik golongan penisilin di RSUD Kuala Kurun selama periode September-November 20 I 5 berjumlah I 32 resep yang keseluruhannya digunakan sebagai sampel. Teknik pengumpulan data yang digunakan berupa dokumentasi yaitu dengan menghitung penggunaan dan mengelompokkan antibiotik golongan penisilin berdasarkan jenis sediaan. Berdasarkan hasil penelitian diketahui bahwa bentuk sediaan antibiotik yang paling banyak digunakan pada periode September-November 2015 adalah sediaan tablet. Penggunaan Amoxicillin tablet diresepkan sebanyak 92 resep dengan persentase penggunaan 69,7\%. Jenis obat Ampicillin tablet diresepkan sebanyak 18 resep dengan persentase penggunaan 13,6\%. Sedangkan antibiotik golongan Penisilin sediaan Amoxicillin sirup total penggunaan sebanyak 22 resep dengan hasil persentase 16,7 \%. Berdasarkan kunjungan pasien yang datang berobat ke RSUD Kuala Kurun pada periode September-November 2015 terdapat I32 resep pasien yang menggunakan antibiotik golongan penisilin. Setelah data dikelompokkan diketahui bahwa bentuk sediaan antibiotik golongan penisilin yang paling banyak digunakan adalah sediaan tablet dengan jenis obat Amoxicillin dan Ampicillin.
\end{abstract}

Kata kunci: Antibiotik golongan penisilin, RSUD Kuala Kurun, Kabupaten Gunung Mas

\begin{abstract}
Antibiotics are chemicals produced by bacteria, which have the ability to kill or inhibit the growth of germs, while the toxicity to humans is relatively small. Based on observations, penicillin is a class of antibiotics that are widely used in Kuala Kurun Hospital especially in outpatients. Penicillin is the most basic antibiotic used for patients who are infected because of low or simpler spectrum in inhibiting bacterial growth. This study aims to determine the profile of the use of penicillin class antibiotics in Kuala Kurun Hospital. The method used in this study is descriptive method, the population in this study were all prescription outpatients that included penicillin group antibiotics at Kuala Kurun Hospital during the period of September-November 2015 totaling I32 prescriptions, all of which were used as samples. Data collection techniques used in the form of documentation is by calculating the use and classifying the antibiotic groups of penicillin based on the type of preparation. Based on the results of the study it was found that the most widely used antibiotic dosage forms in the period September-November 2015 were tablet preparations. The use of Amoxicillin tablets was prescribed for 92 prescriptions with $69.7 \%$ usage percentage. Ampicillin tablets are prescribed as many as 18 prescriptions with a usage percentage of 13.6\%. Whereas antibiotics in the penicillin group, Amoxicillin syrup preparations total use as many as 22 recipes with a percentage of 16.7\%. Based on the visit of patients who came to Kuala Kurun Hospital in the period of September-November 2015 there were 132 prescriptions of patients using penicillin class of antibiotics. After the data is grouped, it is known that the most widely used penicillin antibiotic form is tablet preparation with Amoxicillin and Ampicillin.
\end{abstract}

Keywords: Penicillin class of antibiotic, Kuala Kurun Hospital, Gunung Mas Regency

\section{PENDAHULUAN}

Antibiotik merupakan antibakteri yang dihasilkan dari mikroorganisme atau yang diperoleh dari sintesis yang berasal dari senyawa non organik (Priyanto dalam Ramsinah, 2013). Adapun antibiotik dapat dikelompokkan menjadi 8 golongan yaitu golongan Penisilin, golongan Sefalosporin, golongan Aminoglikosida, golongan Quinolon, golongan Tetrasiklin, golongan Makrolida dan Linkomisin, golongan Polipeptida dan golongan antibiotik lainnya (Tjay\& Rahardja, 2007).

Berdasarkan hasil observasi yang dilakukan, penisilin merupakan golongan antibiotik yang banyak digunakan di RSUD Kuala Kurun khususnya pada pasien rawat jalan yaitu dengan jumlah 180 penggunaan dari bulan Januari sampai 
dengan Juni. Hal ini disebabkan karena golongan penisilin adalah antibiotik yang paling dasar digunakan untuk pasien yang terkena infeksi karena berspektrum rendah atau lebih sederhana dalam menghambat pertumbuhan bakteri. Padatahun 2015 terjadi musim kemarau yaitu pada periode kabut asap puncak pertama muncul di tahun 2015 adalah pada bulan September menurut data yang dihimpun dari Kompas.Faktor cuaca disini yaitu pada siklus ini terjadi musim kemarau yang terjadi antara rentang bulan Juli sampai Desember. Pada musim kemarau banyak sekali pembakaran hutan dan lahan, sehingga menimbulkan kabut asap.Hal inilah yang menyebabkan prevalensi peningkatan pada penyakit Infeksi yang mengakibatkan peningkatan jumlah penggunaan antibiotik.

Penyakit infeksi masih merupakan salah satu masalah kesehatan yang sangat penting, khususnya di negara berkembang dan salah satu obat yang sering digunakan untuk mengatasi penyakit infeksi adalah antibiotik. Berdasarkan data pasien rawat jalan di RSUDKuala Kurun Tahun 20I5, penyakit infeksi berada di urutan ketiga dalam 10 penyakit terbanyak dengan jumlah 169 kasus. Di RSUD Kuala Kurun belum pernah dilakukan penelitian tentang profil antibiotik golongan penisilin. Penelitian ini dilakukan sebagai bahan evaluasi dalam penggunaan dan pengadaan obat antibiotik golongan penisilin untuk periode yang akan datang di RSUD Kuala Kurun. Berdasarkan latar belakang tersebut peneliti tertarik untuk mengetahui "Profil Penggunaan Obat Antibiotik Golongan Penisilin di RSUD Kuala Kurun".

\section{METODOLOGI}

Penelitian ini menggunakan metode Observasional dengan pendekatan Studi Deskriptif. Deskriptif adalah suatu metode penelitian yang dilakukan dengan tujuan utama untuk membuat gambaran deskripsi tentang suatu keadaan secara objektif. Teknik pengambilan sampel yang digunakan pada penelitian ini dengan menggunakan sampling jenuh. Sampling jenuh adalah suatu teknik penentuan sampel bila semua anggota populasi digunakan sebagai sampel (Sangadji, 2010). Sampel yang digunakan pada penelitian ini adalah semua resep rawat jalan yang mencantumkan sediaan antibiotik golongan penisilin di RSUD Kuala Kurun Periode Bulan September-November 2015 yang berjumlah sebanyak 132 resep. Teknik pengumpulan data berupa dokumentasi, yaitu dengan menghitung penggunaan dan mengelompokkan antibiotik golongan penisilin berdasarkan jenis sediaan farmasi di Apotek Rawat Jalan RSUD Kuala Kurun selama periode September sampai dengan November 2015.

\section{HASIL DAN PEMBAHASAN}

Hasil penelitian ini yang didapatkan terkait golongan antibiotik yang digunakan di RSUD Kuala Kurun dapat dilihat pada Tabel I. Berdasarkan Tabel I, golongan antibiotik yang banyak digunakan yaitu golongan Penisilin sebanyak I 32 resep. Hal ini dikarenakan golongan Penisilin merupakan golongan yang paling dasar digunakan untuk mengobati infeksi karena berspektrum rendah atau lebih sederhana dalam menghambat pertumbuhan bakteri.

Tabel I. Golongan Antibiotik yang Digunakan di RSUD Kuala Kurun

\begin{tabular}{clc}
\hline No & Golongan Antibiotik & Jumlah Resep \\
\hline I & Sefalosporin & 46 \\
2 & Kuinolon & 22 \\
3 & Penisilin & 132 \\
\hline & Jumlah (n) & 200 \\
\hline
\end{tabular}

Jumlah resep untuk penggunaan antibiotik golongan Penisillin periode September-November 2015 di Apotek Rawat Jalan RSUD Kuala Kurun Kabupaten Gunung Mas dapat dilihat pada Tabel II.

Tabel II. Jumlah Resep Antibiotik Golongan Penisilin di RSUD Kuala Kurun

\begin{tabular}{cclcc}
\hline No & Bulan & Sediaan & $\begin{array}{c}\text { Jumlah } \\
\text { Resep }\end{array}$ & Total \\
\hline I & September & Tablet & 46 & 52 \\
& & Sirup kering & 6 & \\
2 & \multirow{2}{*}{ Oktober } & Tablet & 34 & 38 \\
& & Sirup kering & 4 & \\
3 & \multirow{2}{*}{ November } & Tablet & 30 & 42 \\
& & Sirup kering & 12 & \\
\hline & & & & 132 \\
\hline
\end{tabular}

Hasil penelitian mengenai profil penggunaan antibiotik golongan Penisilin yang diresepkan oleh dokter di RSUD Kuala Kurun dapat dilihat pada Tabel III. Berdasarkan tabel 3 diatas, jumlah antibiotik golongan Penisilinyang banyak digunakan adalah antibiotik Amoxicillin daripada Ampicillin. $\mathrm{Hal}$ ini disebabkan karena Amoxicillin spektrumnya lebih luas daripada Ampicillin.

Berdasarkan jenis sediaan, antibiotik golongan Penisilin yang digunakan di RSUD Kuala Kurun yaitu sediaan kaplet dan sirup. Antibiotik yang paling banyak diresepkan yaitu Amoxicillin kaplet daripada sediaan sirup (Tabel IV). Hal ini disesuaikan dengan kondisi pasien yang kebanyakan dari golongan dewasa sehingga sediaan kaplet menjadi pilihan yang sering digunakan. 
Tabel III. Jumlah Antibiotik Golongan Penisilin di RSUD Kuala Kurun

\begin{tabular}{|c|c|c|c|c|c|c|c|}
\hline \multirow{2}{*}{$\begin{array}{c}\text { Nama } \\
\text { Obat }\end{array}$} & \multirow[t]{2}{*}{ Sediaan } & \multicolumn{3}{|c|}{$\begin{array}{c}\text { Jumlah } \\
\text { Obat/bulan }\end{array}$} & \multirow{2}{*}{$\begin{array}{c}\text { Jlh } \\
\text { obat }\end{array}$} & \multirow[t]{2}{*}{ Total } & \multirow{2}{*}{$\begin{array}{c}\text { Persen } \\
\text { (\%) }\end{array}$} \\
\hline & & Sep & Okt & Nov & & & \\
\hline Amoxi- & Kaplet & 0 & 0 & 0 & 0 & 18 & 1,60 \\
\hline $\begin{array}{l}\text { cillin } \\
\text { I } 25 \mathrm{mg}\end{array}$ & $\begin{array}{l}\text { Sirup } \\
\text { kering }\end{array}$ & 5 & 4 & 9 & 18 & & \\
\hline Amoxi- & Kaplet & 150 & 110 & 70 & 330 & 334 & 29,76 \\
\hline $\begin{array}{l}\text { cillin } \\
250 \mathrm{mg}\end{array}$ & $\begin{array}{l}\text { Sirup } \\
\text { kering }\end{array}$ & I & 0 & 3 & 4 & & \\
\hline Amoxi- & Kaplet & 240 & 150 & 200 & 590 & 590 & 52,58 \\
\hline cillin & Sirup & 0 & 0 & 0 & 0 & & \\
\hline $500 \mathrm{mg}$ & kering & & & & & & \\
\hline Ampici- & Kaplet & 70 & 80 & 30 & 180 & 180 & 16,04 \\
\hline $\begin{array}{l}\text { Ilin } 500 \\
\text { mg }\end{array}$ & $\begin{array}{l}\text { Sirup } \\
\text { kering }\end{array}$ & 0 & 0 & 0 & 0 & & \\
\hline Jumla & h (n) & 466 & 344 & 312 & 1.122 & 1.122 & 100 \\
\hline
\end{tabular}

Tabel IV. Penggunaan Antibiotik Golongan Penisilin Berdasarkan Jenis Sediaan

\begin{tabular}{lcc}
\hline \multicolumn{1}{c}{ Jenis Sediaan } & Jumlah Resep & Persen (\%) \\
\hline Amoxicillin Kaplet & 92 & 69,7 \\
Amoxicillin Sirup & 22 & 16,7 \\
Ampicillin Kaplet & 18 & 13,6 \\
\hline Jumlah (n) & 132 & 100 \\
\hline
\end{tabular}

\section{KESIMPULAN}

Berdasarkan data hasil penelitian mengenai profil penggunaan antibiotik golongan Penisilin di RSUD Kuala Kurun pada pasien rawat jalan didapat kesimpulan bahwa antibiotik golongan Penisilinyang digunakan pada periode September-November 2015 adalah Amoxicilin $125 \mathrm{mg}$ dengan persentase 1,60\%, Amoxicilin $250 \mathrm{mg}$ dengan persentase $29,76 \%$, Amoxicilin $500 \mathrm{mg}$ dengan persentase 52,58\%, dan Ampicilin $500 \mathrm{mg}$ dengan persentase 16,04\%. Jenis sediaan antibiotik golongan Penisilin yang digunakan di RSUD Kuala Kurun adalah Amoxicilin sediaan kaplet dengan total penggunaan sebanyak 92 resep $(69,7 \%)$, Ampicilin sediaan tablet dengan total penggunaan sebanyak 18 resep (13,6\%) dan Amoxicilin sediaan sirup dengan total penggunaan sebanyak 22 botol (16,7\%).

\section{DAFTAR PUSTAKA}

Anief, M. 2000. Ilmu meracik Obat Teori dan Praktek Cetakan ke 9.. Yogyakarta: Gadjah Mada University.

Notoatmodjo, Soekidjo. 2005, Metodologi Penelitian Kesehatan. Jakarta: Rineka Cipta.

Sangadji. 20I0. Metodologi Penelitian Pendekatan Praktis dalam Penelitian. Yogyakarta : ANDI
Sibagariang, Eva Ellya dkk. 20I0. Metodologi Penelitian Untuk Mahasiswa Diploma Kesehatan. Jakarta : Trans Info Media.

Siregar, J. P. Charles., 2003. Farmasi Rumah Sakit Teori dan Terapan.Jakarta : Buku Kedokteran EGC.

Supardi, Sudibyo dan Surahman. 2014. Metodologi Penelitian Untuk Mahasiswa Farmasi. Jakarta Timur : CV Trans Info Media.

Syarif, A. 2007. Farmakologi dan Terapi Edisi 5. Jakarta : Departemen Farmakologi dan Terapeutik Fakultas Kedokteran Universitas Indonesia.

Tan Hoan Tjay, Kirana Rahardja. 2007. Obat-Obat Penting. Jakarta: PT Elex Media Komputindo Kelompok Gramedia. 